\title{
Epicardial damage induced by topical cooling during paediatric cardiac surgery
}

Antonio Corno, Elena Zoia, Francesco Santoro, Chiara Camesasca, Bonizella Biagioli, Adalberto Grossi

\begin{abstract}
Objective-To study electrocardiographic changes in infants and children in whom topical cooling was used during surgical repair of congenital heart defects.

Design-A retrospective study of all patients who had surgical repair of congenital heart disease during cold blood cardioplegia and topical cooling from January to August 1990. Eleven patients (group 1) had topical cooling with ice and 15 (group 2) with cold saline.

Patients-All 36 paediatric patients operated on during this period. All the available electrocardiographic records were analysed. Ten patients in whom reliable records were not available were excluded. Twenty six patients entered in this retrospective study.
\end{abstract}

Interventions-Topical cooling with ice or with a slush of cold saline.

Main outcome measure-Recordings from all the precordial leads were examined and scored as the sum of the maximum ST elevation (mV) in each precordial lead. The score obtained for each electrocardiogram was recorded together with the timing of the electrocardiogram (preoperative, arrival in intensive care unit immediately after surgery, postoperatively in the intensive care unit, and at discharge).

Results-There were no differences between the two groups in terms of demographic data, diagnosis, duration of ischaemia, and postoperative myocardial performance. There was temporary ST elevation during the first 48 postoperative hours in all the children in group 1 but in only seven of the 15 children in group 2 (Fisher's test, p $<0.005$ ). The mean (SD) score for maximum ST elevation was 1.34 (0.83) $\mathrm{mV}$ in group 1 and $0.52(0.64) \mathrm{mV}$ in group 2 (Student's $t$ test, $p<0.01$ ).

Conclusions-These temporary electrocardiographic changes in the presence of adequate myocardial performance were attributed to epicardial damage induced by hypothermicosmotic injury. The use of ice for topical cooling may damage the epicardium in children.

Topical cardiac hypothermia, used alone or in conjunction with cold cardioplegia, is a simple and effective means of protecting the myocardium during cardiac surgery. ${ }^{1-15}$ Topica cooling, however, can damage the phrenic nerve $\mathrm{e}^{124-11}$ and the myocardium. ${ }^{16-23} \mathrm{We}$ saw temporary electrocardiographic variations that were probably caused by epicardial damage in children in whom topical cooling was used during surgical repair for congenital heart defects.

\section{Patients and methods}

From January to August 199036 children had surgical repair of a congenital heart defect on cardiopulmonary bypass. In all patients the myocardium was protected by moderate hypothermia, cold blood cardioplegia, modified warm blood reperfusion, and topical cooling during the ischaemic period.

Initially (January to April 1990) we used ice for topical cooling. Later (April to August $1990)$ we used a slush of cold saline $\left(4-8^{\circ} \mathrm{C}\right)$ without ice. We retrospectively compared the patients treated by these two methods in terms of age, weight, diagnosis, duration of cardiopulmonary bypass and aortic cross clamping time, myocardial enzymes (creatine kinase and creatine kinase $\mathrm{MB}$ ), electrocardiograms, and clinical indices in the intensive care unit (peripheral pulses, peripheral temperature, oxygen saturation of the mixed venous blood, time of extubation, need for inotropic support length of stay).

All the available electrocardiograms were analysed. We examined the traces from all the precordial leads and obtained an arbitrary score by adding the maximum ST elevation $(\mathrm{mV})$ seen in each precordial lead. ${ }^{24}{ }^{25}$ The score for each electrocardiogram was recorded, together with the timing of the electrocardiogram (that is, preoperative, arrival in the intensive care unit immediately after surgery, postoperatively in the intensive care unit, and at discharge).

We excluded patients for whom we did not have a complete set of electrocardiograms and those who required activation of an external pacemaker during the postoperative electrocardiographic recording. All the electrocardiograms were analysed by a cardiologist (CC) who was unaware of the type of topical cooling used and of the timing of the electrocardiogram.

We used Fisher's test to compare the two groups in terms of the presence or absence of ST elevation and Student's $t$ test to compare the two groups in terms of the score for maximum ST elevation. A probability of $<0.05$ was regarded as significant. \\ Centre, Univers \\ Italy \\ E Zoia \\ C Camesasca \\ Correspondence to \\ Dr Antonio Corno,
}


Table 1 Clinical data

\begin{tabular}{lcc}
\hline Data & $\begin{array}{l}\text { Group 1 } \\
\text { (topical cooling with ice) }\end{array}$ & $\begin{array}{l}\text { Group 2 } \\
\text { (topical cooling without ice) }\end{array}$ \\
\hline Number of patients & 11 & 15 \\
Mean age (range) (yr) & $7 \cdot 7(4 \cdot 4-15 \cdot 1)$ & $5 \cdot 8(0 \cdot 8-14 \cdot 2)$ \\
Mean weight (range) (kg) & $25 \cdot 0(15-56)$ & $19 \cdot 3(6-47)$ \\
Mean duration of CPBP (range) (min) & $53(36-70)$ & $72(28-150)$ \\
Mean aortic cross clamp (range) (min) & $22(12-37)$ & $35(7-74)$ \\
Mean CK (range) (U/1) & $674(147-2130)$ & $874(318-1642)$ \\
Mean CK MB (range)(U/1) & $61(20-118)$ & $98(37-196)$ \\
\hline
\end{tabular}

CPBP, cardiopulmonary bypass; $\mathrm{CK}$, creatine kinase.

There were no significant differences between group 1 and group 2 (Wilcoxon test).

\section{Results}

We analysed data for 11 patients who had topical cooling with ice (group 1) and 15 patients who had topical cooling without ice (group 2) (table 1). The diagnoses in group 1 patients were subaortic stenosis four, atrial septal defect three, aortic valve stenosis two, partial atrioventricular septal defect one, and partial anomalous pulmonary venous connection one. In group 2 patients the diagnoses were atrial septal defect five, ventricular septal defect three, partial atrioventricular septal defect two, tetralogy of Fallot two, subaortic stenosis one, aortic valve stenosis one, and partial anomalous pulmonary venous connection one.

There wereno significant differences between the two groups in terms of age, weight, duration of cardiopulmonary bypass, duration of aortic cross clamping, and activity of creatine kinase and creatine kinase MB (table 1). Nor were there any differences between the two groups in terms of the indirect signs of adequate cardiac output during the postoperative course (peripheral pulses, peripheral temperature, oxygen saturation of the mixed venous blood), early extubation, the need for inotropic support, and stay in the intensive care unit.

All patients in group 1 showed ST elevation in the first $\mathbf{4 8}$ hours after operation but only seven $(47 \%)$ of the patients in group 2 $(p<0.005)$. In group 1 the mean (SD) of the highest electrocardiographic scores was 1.34 $(0.83)(0.5-2.85) \mathrm{mV}$ whereas in group 2 it was $0.52(0.64)(0-1.5) \mathrm{mV},(\mathrm{p}<0.01)$ (table 2). None of the patients had electrocardiographic changes on the first postoperative recording (at arrival in the intensive care unit). The ST changes became evident 8-16 hours after operation and then progressively diminished 24-48 hours after operation. No ST segment elevation was seen on any of the electrocardiograms recorded at discharge (figure).

Mean (SD) $1.34(0.83)$

Group 2

\begin{tabular}{ll} 
(topical cooling without ice) \\
1 & 0.25 \\
2 & 1.50 \\
3 & 1.30 \\
4 & 1.45 \\
5 & 0 \\
6 & 1.20 \\
7 & 0 \\
8 & 0.95 \\
9 & 0 \\
10 & $1 \cdot 20$ \\
11 & 0 \\
12 & 0 \\
13 & 0 \\
14 & 0 \\
15 & 0 \\
Mean (SD) & $0.52(0.64)$ \\
\hline
\end{tabular}
surface/wall thickness ratio than the adult heart. $^{27}$ In an experimental study of the isolated, blood perfused neonatal heart adequate myocardial recovery was reported

\section{Discussion}

Topical cooling has been reported to provide better structural and functional protection of The myocardial protection provided by topical cooling is even more efficient in neonates than in children. Faster and more uniform cooling can be obtained in the neonatal heart because it has a relatively small cardiac mass and a greater after two hours of ischaemia with topical cooling as the only method of myocardial protection. ${ }^{27}$ We have always used topical cooling with blood cardioplegia for myocardial protection in our paediatric patients. Damage to the phrenic nerve ${ }^{1248-11}$ and to the myocardium ${ }^{16-23}$ induced by topical cooling has often been reported but we were unaware of epicardial damage in children with this method of myocardial protection.

In our retrospective study we found evidence of temporary ST changes in all the patients in whom topical cooling was achieved with ice (group 1) but in only half of those in whom topical cooling was achieved with cold saline without ice (group 2). Whatever the method we used for topical cooling myocardial protection was adequate in all our patients. We therefore examined the possibility that the epicardium had been temporarily damaged by prolonged direct contact with the ice. An interesting study showed that ice crystals only form after the saline is "supercooled" to $-7^{\circ} \mathrm{C}$ and that this causes the surrounding cold solution to become hyperosmotic. ${ }^{18}$ This thermodynamic effect could lead to hypothermic-osmotic tissue damage during topical cardiac cooling. The commonest example of this is paralysis of the phrenic nerve. ${ }^{1248-11}$

The degree of hypothermic-osmotic damage that could be caused by topical cooling of the myocardium is less well understood. Direct hypothermic damage to the heart muscle may result in disorganisation of the protoplasmic structure of the cell surface, possibly by drastically dehydrating the fluid layer surrounding the protoplasmic surface. ${ }^{18}$ Muscle cell membranes start to leak and proteins become denatured when their temperature is lowered to a critical "point of no return". This "point of no return", however,
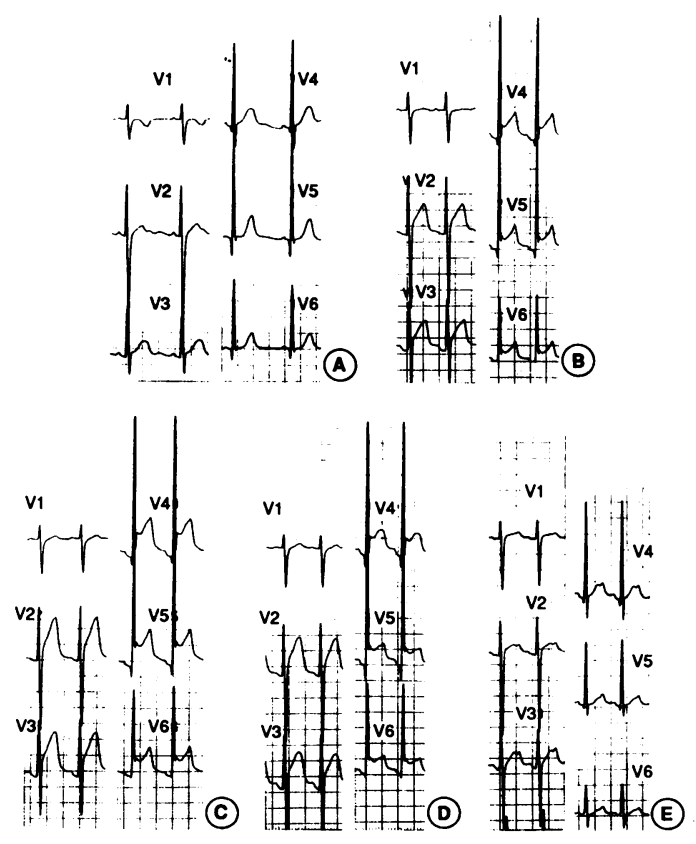

Electrocardiogram in a child (case 9) in whom ice was used for topical cooling (group 1). (A) preoperative recording; $(B),(C)$, and $(D) 6,11$, and 16 hours postoperatively; (E) at discharge. 
has never been accurately defined. ${ }^{18}$ Electron microscopic studies of smooth muscle preparations showed that this process was already evident at temperatures as high as $-2 \cdot 5^{\circ} \mathrm{C} .^{23}$

As the muscle is frozen to $-20^{\circ} \mathrm{C}$ more and more cells show signs of severe structural damage such as disrupted plasma membranes and mitochondria, gross alterations to contractile myofilaments, complete disintegration of myofilaments and shrinkage of nuclei. ${ }^{23}$ Walter also found that hypertonic salt solutions damaged smooth muscle and he concluded that sodium chloride is the electrolyte that is most likely to cause damage during freezing and thawing. ${ }^{23}$ Furthermore the myocardial storage temperature affects the recovery of calcium ATPase: after storage at $0-4^{\circ} \mathrm{C}$ recovery of calcium ATPase function was poor, which may be an explanation for the abnormal relaxation of stored myocardium. ${ }^{16}$

We examined our clinical experience in the light of these reported experimental observations. We found that $(a)$ the electrocardiographic changes we saw were completely different from the $T$ wave changes seen after the pericardiotomy; (b) the electrocardiographic changes occurred even when myocardial performance was adequate. (This fact supports our hypothesis that the temporary ST elevation was an expression of epicardial damage without depression of the myocardial function.); (c) the ST changes coincided with the appearance of epicardial oedema within a few hours of the hypothermic-osmotic damage, and subsequently disappeared with routine fluid restriction and use of diuretics in the first 48 hours after operation.

We conclude that (a) the topical cooling obtained with ice may induce temporary epicardial damage in children even when there are no adverse clinical occurrences; $(b)$ the potential for hypothermic-osmotic injury should be borne in mind whenever topical cardiac hypothermia is used; (c) epicardial damage can be avoided if cold saline is used instead of ice for topical cooling (cold blood cardioplegia with modified reperfusion and topical cooling with cold saline gives adequate myocardial protection).

1 Brody WR, Reitz BA. Topical hypothermia protection of the myocardium Ann Thorac Surg 1975;20:66.

2 Cohn LH, Collins JJ. Local cardiac hypothermia for myocardial protection. Ann Thorac Surg 1974;17:135.

3 Cross RS, Jones RD, Berne RM. Localised cardiac hypothermia as an adjunct to elective cardiac arrest. Surg Forum 1957;8:355-63.

4 Griepp RB, Stinson EB, Oyer PE, Copeland JG, Shumway
NE. The superiority of aortic cross-clamping with profound local hypothermia for myocardial protection profound local hypothermia for myocardial protection during aorta-coronary bypass
Cardiovasc Surg 1975;70:995-1009.

5 Holland CE, Olson RE. Prevention by hypothermia of paradoxical calcium necrosis in cardiac muscle. J Mol Cell Cardiol 1975;7:917-28.

6 Hufnagel CA, Conrad PW, Schanno J, Pifarré R. Profound cardiac hypothermia. Ann Surg 1961;153:790-6.

7 Koster JK, Cohn LH, Collins JJ, Sanders JH, Muller JE Young E. Continuous hypothermic arrest versus intermittent ischemia for myocardial protection during coronary revascularisation. Ann Thorac Surg 1977;24:330.

8 Lazar HL, Rivers S. Importance of topical hypothermia during heterogeneous distribution of cardioplegic solution. J Thorac Cardiovasc Surg 1989;98:251-7.

9 Laschinger JC, Catinella FP, Cunningham JN, Knopp EA, Nathan IM, Spencer FC. Myocardial cooling: beneficia effect of topical hypothermia. J Thorac Cardiovasc Surg 1982;84:807-14.

10 Pupello DF, Blank LH, Bessone LN, Connar RG, Carlton LM. Local deep hypothermia for combined valvular and coronary heart disease. Ann Thorac Surg 1976;21:508.

11 Sanger PW, Robicsek F, Daugherty HK, Gallucci V, Lesage MA. Topical cardiac hypothermia in lieu of coronar perfusion. J Thorac Cardiovasc Surg 1966;52:533-41.

12 Schraut W, Lamberti JJ, Kampman K, Anagnostopoulos C Replogle R, Glagov S. Does local cardiac hypothermi during cardiopulmonary bypass protect the myocardium from long-term morphological and functional injury? $A n$ Thorac Surg 1977;24:315.

13 Shragge BW, Digerness SB, Blackstone EH. Complete recovery of myocardial function following cold exposure. Circulation 1978;58 (suppl II):II-97.

14 Shumway NE, Lower RR, Stofer RC. Selective hypothermia of the heart in cardiac arrest. Surg Gynecol Obstet 1959;100:750-4.

15 Swanson DK, Dufek JH, Kahn DR. Improved myocardial preservation at $4^{\circ} \mathrm{C}$. Ann Thorac Surg 1980;30:519-26.

16 Labow RS, Meek E, Hendry PJ, Keon WJ. Temperature affects human sarcoplasmatic reticulum calcium ATPase. J Mol Cell Cardiol 1990;22 (suppl V):12.

17 Rittenhouse EA, Mohri H, Reichenbach DD, Merendino KA. Morphological alterations in vital organs after prolonged cardiac arrest at low body temperature. $A n n$ Thorac Surg 1972;13:564-74.

18 Robicsek F, Duncan GD, Rice HE, Robicsek SA Experiments with a bowl of saline: the hidden risk of hypothermic-osmotic damage during topical cardiac cooling. $J$ Thorac Cardiovasc Surg 1989;97:461-6.

19 Rosenfeldt FL, Cochrane AD. When is hypothermic tech nique inadequate? How can it be improved? J Mol Cell Cardiol 1990;22 (suppl V):45.

20 Sarajas HSS. Myocardial damage induced by immersion hypothermia. Am J Cardiol 1964;13:355-66.

21 Speicher CE, Ferrigan L, Wolfson SK, Yalav EH, Rawson AJ. Cold injury of myocardium and pericardium in cardiac

22 Tyers GFO, Williams EH, Huges HC, Todd GJ. Effect of perfusate temperature on myocardial protection from perfusate temperature on myocardial protection fror

23 Walter CA. Ultrastructural and functional changes in smooth muscle associated with freezing and thawing. In: Popovic V, Popovic P, eds. Hypothermia in biology and medicine. New York: Grune and Stratton, 1974:271-93.

24 Maroko PR, Libby P, Covell JW, Sobel BE, Ross J Braunwald E. Precordial S-T segment elevation mapping: an atraumatic method for assessing alterations in the extent of myocardial ischemic injury. $A m J$ Cardio 1972;29:223-30.

25 Nikutta P, Haussmann D, Wenzlaff P. ST analysis: intragroup versus intrapatient variability of Holter results [abstract]. J Am Coll Cardiol 1989;13:189.

26 Bove EL, Stammers AH. Recovery of left ventricular function after hypothermic global ischemia: age-related differences in the isolated working rabbit heart. $J$ Thorac Cardiovasc Surg 1986;91:115-32.

27 Corno AF, Bethencourt DM, Laks $\mathrm{H}$, et al. Myocardial protection in the neonatal heart. $J$ Thorac Cardiovasc Surg 1987;93:163-72

28 Lamberti JJ, Cohn LH, Laks H, Braunwald NS, Collins JJ Castaneda AR. Local cardiac hypothermia for myocardial protection during correction of congenital heart disease. Ann Thorac Surg 1975;20:446-54. 